\title{
Coagulase-positive methicillin-resistant Staphylococcus aureus circulating in clinical mastitic goats in Bangladesh
}

\author{
Eaftekhar Ahmed Rana1(D), Tridip Das ${ }^{1}$ (D), Avijit Dutta1(D), Mizanur Rahman², Mohammad Bayazid Bostami², Nasima Akter ${ }^{3}$ (D) \\ and Himel Barua1(iD)
}

\begin{abstract}
1. Department of Microbiology and Veterinary Public Health, Chattogram Veterinary and Animal Sciences University Chattogram, Bangladesh; 2. Teaching and Training Pet Hospital and Research Center, Chattogram Veterinary and Animal Sciences University, Chattogram, Bangladesh; 3. Department of Dairy and Poultry Science, Chattogram Veterinary and Animal Sciences University, Chattogram, Bangladesh.

Corresponding author: Eaftekhar Ahmed Rana, e-mail: eaftekhar787@gmail.com

Co-authors: TD: das.vet671@gmail.com, AD: avijit@cvasu.ac.bd, MR: mizan.dvm20@gmail.com, MBB: bayazid.vet39@gmail.com, NA: shumi.cvasu13@gmail.com, HB: himel.barua@gmail.com

Received: 17-12-2019, Accepted: 14-05-2020, Published online: 11-07-2020
\end{abstract}

doi: www.doi.org/10.14202/vetworld.2020.1303-1310 How to cite this article: Rana EA, Das T, Dutta A, Rahman M, Bostami MB, Akter N, Barua H (2020) Coagulase-positive methicillin-resistant Staphylococcus aureus circulating in clinical mastitic goats in Bangladesh, Veterinary World, 13(7): 1303-1310.

\begin{abstract}
Background and Aim: Staphylococcus aureus is argued as one of the principal organisms responsible for mammary gland infection in lactating goats, causing both clinical and subclinical mastitis. Being highly zoonotic potential, pathogen emergence of methicillin-resistant $S$. aureus (MRSA) has a significant clinical impact on treatment and management of clinical mastitis. We conducted a cross-sectional study to investigate the prevalence of coagulase-positive $S$. aureus (CoPS), antimicrobial resistance profile of Staphylococcus spp., prevalence of MRSA, and association between different clinical parameters with CoPS.
\end{abstract}

Materials and Methods: A total of 67 clinical mastitic goats were sampled based on clinical examination and California mastitis test. Standard bacteriological methods were performed to isolate and identify Staphylococcus spp. CoPS were confirmed by nuc gene using polymerase chain reaction (PCR). All staphylococcal isolates were further examined for antimicrobial susceptibility testing by disk diffusion method. MRSA was confirmed based on mecA gene-based PCR.

Results: Here, 49 (73.13\%; 95\% confidence interval [CI], 61.41-82.35) samples were positive for Staphylococcus spp., of which 17 (34.69\%; 95\% CI, 22.88-48.73) isolates were CoPS and rest of the isolates (32; 65.30\%; 95\% CI, 51.27-77.12) were identified as coagulase-negative Staphylococcus spp. (coagulase-negative staphylococci [CNS]). Both, CoPS and CNS isolates displayed the highest resistance against tetracycline (76.47\% and $75 \%$, respectively) and oxacillin (70.58\% and $68.75 \%$, respectively). Notably, all staphylococcal isolates were multidrug-resistant (showed resistance to $\geq 3$ classes of antimicrobials). mecA gene was found in 6 (8.96\%; 95\% CI, 3.84-18.52) CoPS isolates indicating MRSA strains. Among different clinical parameters, presence of high body temperature $(p<0.05)$, firm udder consistency $(p<0.01)$, bloodstained milk $(\mathrm{p}<0.00)$, and pus in milk $(\mathrm{p}<0.00)$ were significantly associated with the presence of CoPS in mastitic caprine milk.

Conclusion: To the best of our knowledge, this is the first report of MRSA isolated from clinical caprine mastitis cases in Bangladesh. The findings of this study would help in cautious selection as well as administration of antimicrobials for therapeutic management of mastitic goats.

Keywords: Antimicrobial resistance, clinical mastitis, coagulase-positive Staphylococcus aureus, goat, methicillin-resistant Staphylococcus aureus.

\section{Introduction}

Mastitis is one of the most challenging production diseases for lactating animals, particularly for bovine, ovine, and caprine all over the world. Diverse groups of pathogens, especially bacteria, frequently act as etiological agent for mammary gland infections. Among the pathogens, Staphylococcus aureus is the most frequently isolated contagious bacterial pathogen [1]. Due to carriage of multiple virulence factors, of $S$. aureus is

Copyright: Rana, et al. Open Access. This article is distributed under the terms of the Creative Commons Attribution 4.0 International License (http://creativecommons.org/licenses/by/4.0/), which permits unrestricted use, distribution, and reproduction in any medium, provided you give appropriate credit to the original author(s) and the source, provide a link to the Creative Commons license, and indicate if changes were made. The Creative Commons Public Domain Dedication waiver (http://creativecommons.org/ publicdomain/zero/1.0/) applies to the data made available in this article, unless otherwise stated. responsible for acute, chronic, and gangrenous mastitis in lactating goats [2]. In this regard, for clinical recovery, caprine mastitis is treated with different groups of broad-spectrum antimicrobials that create potential force to kill or inhibit the growth of bacteria. Due to continuous exposure of antimicrobial agents, it ultimately creates selection pressure and results in emergence of resistant strain of the bacteria [3].

In recent years, methicillin-/oxacillin-resistant staphylococcal strains create a serious clinical perplexity to treat the caprine mastitis. Methicillin-resistant S. aureus (MRSA) strains possess mecA gene, which codes for the expression of penicillin-binding protein (PBP2a, an altered form of PBP2), resulting decreased affinity of methicillin as well as all $\beta$-lactam antibiotics to bind with bacterial cell wall [4]. Ultimately, $S$. aureus has developed multidrug resistance with a 
wide variation from animal to animal [5] and makes difficulties in clinical management of mastitis. As a result, multidrug-resistant (MDR) mastitis pathogens, particularly methicillin-resistant staphylococcal strains, are considered a well-documented threat to the dairy goat production [6]. Although livestock-associated MRSA (LA-MRSA) was reported in very early period in farm animals [7], reports on MRSA have tremendously been increased day by day across the globe [8]. The emergence of MRSA in food animals is alarming for animal professionals, farmers, as well as persons who come in close contact with animals regularly [6,9]. On the other hand, animals harboring MRSA continuously disseminate this MDR potential zoonotic pathogen toward the human and other animal communities. Furthermore, series of reports mention that both pet and food animals act as potential reservoir of human infections with MRSA [10-13]. From public health aspect, there is a possible chance of transmission of MRSA strains from animals to humans who rear animals or consume the ultimate farm products $[8,9,13,14]$. However, the occurrence of MRSA as a causal agent of caprine mastitis remains underreported, if not unreported in Bangladesh. Hence, it is a timely demand to investigate the presence of MRSA in mastitis affected lactating goats aiming to formulate effective preventive measures guideline.

The study was designed to investigate the prevalence of coagulase-positive $S$. aureus (CoPS) as well as antimicrobial sensitivity profile of Staphylococcus spp. with molecular identification of MRSA and, finally, to find out the association between CoPS and different clinical parameters of mastitic goats.

\section{Materials and Methods}

\section{Ethical approval and Informed consent}

In this study, we used only mastitic milk that was collected with minimum discomfort of animals for clinical inspection of mastitic milk for diagnostic as well as treatment purposes in Teaching Veterinary Hospital (TVH). Therefore, verbal permission from animal owners and hospital director of Chattogram Veterinary and Animal Sciences University (CVASU) was taken to conduct the research.

\section{Study area and duration}

A cross-sectional study was conducted at TVHCVASU, Chattogram, Bangladesh, for a period of 10 months (July 2018-April 2019). Goats from different areas of Chattogram are regularly brought to TVHCVASU for different therapeutic purposes. The targeted population was the mastitic goats among them.

\section{Data collection}

A pre-tested questionnaire was used to collect the mastitic goat's data from the respective owner. Clinical data for each case were recorded during clinical examination of the patients (mastitic goat) at the hospital.

\section{Assessment of clinical mastitis}

Clinical mastitis of goat was primarily diagnosed by clinical examination, including palpation and observation of the udder. Visual confirmation of clinical mastitis was based on the presence of indurations of one or both quarters, swelling of udder, abnormal secretion of milk including flaky clots, discoloration of milk including decreased surface tension, and blood stained secretion from udder. Presence of redness, heat, and pain found on palpation of udder were treated as clinical mastitis. In addition, goats with high body temperature, loss of appetite, decrease milk production, dullness, and depression were considered as associated clinical signs of clinical mastitis.

California mastitis test (CMT) was performed for further confirmation of clinical mastitis cases. CMT was performed according to the manufacturer's instructions (Leukocytest ${ }^{\mathbb{Q}}$, Synbiotics Corporation, France). Approximately $2 \mathrm{ml}$ of milk was taken from individual teat of the goat in each well of the test plate. Then, equal amount $(2 \mathrm{ml}$ ) of CMT reagent was added in the test well and circular motion was made for mixing the reagents and milk. Finally, the test results were interpreted as negative (somatic cell count [SCC] score of $\leq 100,000$ cells $/ \mathrm{ml}$ ), weak positive (1+; SCC score of $>100,000-500,000$ cells $/ \mathrm{ml}$ ), distinct positive (2+; SCC score of $>500,000-1,000,000$ cells $/ \mathrm{ml}$ ), and strong positive ( $3+$; SCC score of $\geq 1,000,000$ cells $/ \mathrm{ml}$ ) according to the manufacturer's instruction [15].

\section{Bacterial isolation and identification}

For bacterial isolation, first, $20 \mu \mathrm{l} \mathrm{CMT-positive}$ mastitic milk sample was cultured on $5 \%$ bovine blood agar (Oxoid Ltd., UK). The inoculated blood agar plates were incubated at $37^{\circ} \mathrm{C}$ for $48 \mathrm{~h}$ aerobically. Colonies displaying the characteristic growth of staphylococci on blood agar (pigmented, raised, medium-sized, and hemolytic) were primarily selected for phenotypic characterization. The presumptive staphylococci colonies were subcultured onto mannitol salt agar (Oxoid Ltd., UK) and incubated for $24 \mathrm{~h}$ at $37^{\circ} \mathrm{C}$. Presumptive colonies were further confirmed using Gram staining and catalase test. All staphylococcal isolates were subjected to the tube coagulase test, as described by Carfora et al. [16]. Isolates were then stored at $-80^{\circ} \mathrm{C}$ using $50 \%$ glycerol until further examination.

\section{Molecular identification of $S$. aureus by nuc gene polymerase chain reaction (PCR)}

All staphylococcal isolates were subcultured on blood agar. Bacterial genomic DNA was extracted using crude boiling lysis method [17]. Finally, CoPS was confirmed by the PCR amplification of nuc gene (a characteristic thermonuclease gene of $S$. aureus). For PCR, the primer sequences used were au-F3 (Forward) 5' TCGCTTGCTATGATTGTGG $3^{\prime}$ and au-R (Reverse) 5' GCCAATGTTCTACCATAGC 3'. The amplification condition was as follows: Initial denaturation at $95^{\circ} \mathrm{C}$ for $2 \mathrm{~min}$, followed by 30 cycles 
of final denaturation at $95^{\circ} \mathrm{C}$ for $30 \mathrm{~s}$, annealing at $56^{\circ} \mathrm{C}$ for $35 \mathrm{~s}$, initial extension at $72^{\circ} \mathrm{C}$ for $60 \mathrm{~s}$, and final extension at $72^{\circ} \mathrm{C}$ for $2 \mathrm{~min}$ [18]. For positive and negative controls, S. aureus ATCC 29213 strain and nuclease-free water were used, respectively.

\section{Antimicrobial susceptibility testing}

All staphylococcal isolates were tested against 13 different antimicrobials of various groups using disk diffusion method [19]. The antimicrobials used were ampicillin $(10 \mu \mathrm{g})$, ciprofloxacin $(5 \mu \mathrm{g})$, gentamicin $(30 \mu \mathrm{g})$, tetracycline $(30 \mu \mathrm{g})$, erythromycin $(15 \mu \mathrm{g})$, oxacillin $(5 \mu \mathrm{g})$, amoxicillin $(10 \mu \mathrm{g})$, cefaclor $(30 \mu \mathrm{g})$, sulfamethoxazole- trimethoprim $(23.75+1.25 \mu \mathrm{g})$, cefoxitin $(10 \mu \mathrm{g})$, ceftriaxone $(10 \mu \mathrm{g})$, penicillin(10 IU), and streptomycin $(100 \mu \mathrm{g})$ (Oxoid, Basingstoke, UK). For each isolate, the zone of inhibition was measured and interpreted as susceptible (S), intermediate (I), and resistant (R) according to CLSI guidelines [19]. Isolates resistant to $\geq 3$ classes of antimicrobials were considered as MDR [5].

\section{Molecular identification of mecA gene}

$S$. aureus isolates showing resistance to oxacillin and cefoxitin were primarily considered as MRSA [20]. Only phenotypically resistant isolates were further investigated for the presence of mecA gene by PCR, as described by Larsen et al. [21]. Primers used were mec $A$ P4 (Forward) 5' TCCAGATTACAACTTCACCAGG $3^{\prime}$ and mecA P7 (Reverse) 5' CCACTTCATATCTTGTAACG 3'. The PCR amplification program consisted of initial denaturation at $94^{\circ} \mathrm{C}$ for $15 \mathrm{~min}$, followed by $35 \mathrm{ampli}-$ fication cycles at $94^{\circ} \mathrm{C}$ for $30 \mathrm{~s}$, annealing at $55^{\circ} \mathrm{C}$ for $45 \mathrm{~s}$, and final extension at $72^{\circ} \mathrm{C}$ for $1 \mathrm{~min}$ [21]. MRSA ATCC 33591 strain and nuclease-free water were used as positive and negative controls, respectively.

\section{Statistical analyses}

Data obtained from both bacteriology and questionnaires were entered into Microsoft Excel 2007 and analysis was performed using "R" Program (version 3.5.1) [22]. The prevalence was calculated, dividing the number of positive cases by the total number of goats sampled. All recorded clinical parameters were analyzed for one target outcome of nuc gene-positive $S$. aureus (CoPS). First, univariable analysis was performed to identify possible clinical condition(s) associated with $n u c$ gene-positive $S$. aureus. Any clinical parameter(s) having $\mathrm{p} \leq 0.20$ was entered into multivariable logistic regression model. Forward stepwise selection approach was used to build the final model. Variables with $\mathrm{p} \leq 0.05$ were considered as significant and kept in the final model. The logistic regression analysis was performed using the glmer function from the lme4 package in $\mathrm{R}$ version 3.5.1 [22].

\section{Results}

\section{Categories of clinical mastitis based on CMT}

Out of 67 clinical cases, 48 (71.64\%; 95\% CI, 59.85-81.09) cases were identified as distinct positive
(2+), whereas only $11(16.41 \%$; 95\% CI, 9.25-27.23) and $8(11.94 \%$; $95 \%$ CI, 5.92-22.09) cases were diagnosed as weak positive $(1+)$ and strong positive $(3+)$, respectively. However, none of the clinical cases were found CMT negative.

\section{Bacteriological analyses}

Overall, 49 (73.13\%, 95\% CI, 61.41-82.35) samples were found to be positive for staphylococci, of which 17 (34.69\%, 95\% CI, 22.88-48.73) isolates carried nuc gene (Figure-1) and thus identified as CoPS, and remaining $32(65.30 \%, 95 \% \mathrm{CI}, 51.27-77.12)$ isolates were coagulase-negative staphylococci (CNS) (Table-1).

\section{Antimicrobial susceptibility profiles}

All the CoPS and CNS isolates were found to be MDR (i.e., resistant to $\geq 3$ antimicrobial classes) (Figure-2). In both cases, the highest resistance was observed against tetracycline $(76.47 \%, 95 \%$ CI, 52.23-90.95 and 78.13\%, 95\% CI, 60.96-89.27, respectively) followed by oxacillin $(70.58 \%, 95 \%$ CI, 46.57-87.01 and $68.75 \%, 95 \%$ CI, 51.32-82.16, respectively). More than 58\% isolates were resistant to gentamycin, erythromycin, amoxicillin, and streptomycin in case of CoPS isolates (Table-1). Whereas, around $60 \% \mathrm{CNS}$ isolates displayed resistance against ampicillin, penicillin, gentamycin, and streptomycin (Table-1). However, $70.58 \%$ CoPS isolates were susceptible to ceftriaxone and more than $65 \%$ CNS isolates were susceptible to cefoxitin and ciprofloxacin, respectively (Table-1).

\section{MRSA}

Of the 67 clinical mastitic goats, $6(8.96 \%, 95 \%$ CI 3.84-18.52) were positive for mecA gene. Notably, all mecA genes were carried by CoPS and classified as MRSA (Figure-3).

\section{Association of CoPS with different clinical parame- ters of mastitic goats}

The univariable analysis identified nine clinical parameters $(\mathrm{p} \leq 0.2)$ to be associated with the carriage of nuc gene-positive $S$. aureus in mastitic goats

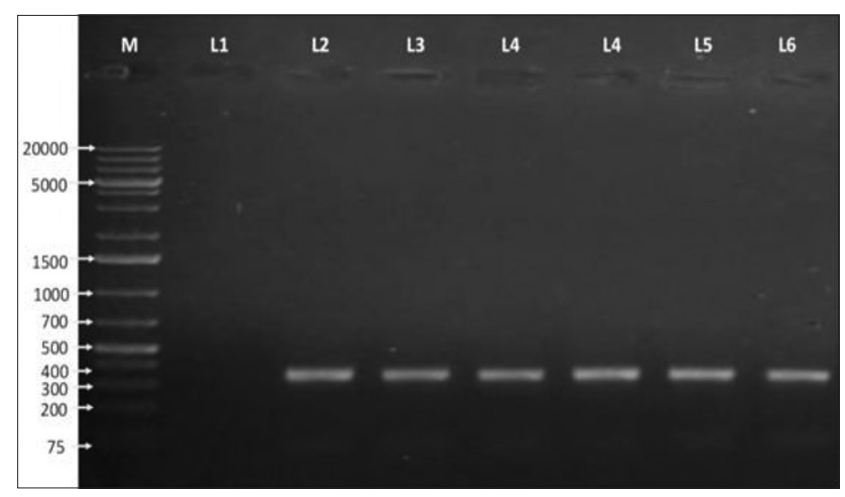

Figure-1: Agarose gel electrophoresis (1\% agarose) image of polymerase chain reaction products of coagulasepositive Staphylococcus aureus (CoPS) isolates showing specific amplified bands $359 \mathrm{bp} . \mathrm{M}=1 \mathrm{~kb}$ plus DNA marker, L1=Negative control, L2=Positive control (ATCC 29213), L3-L6=CoPS isolates. 


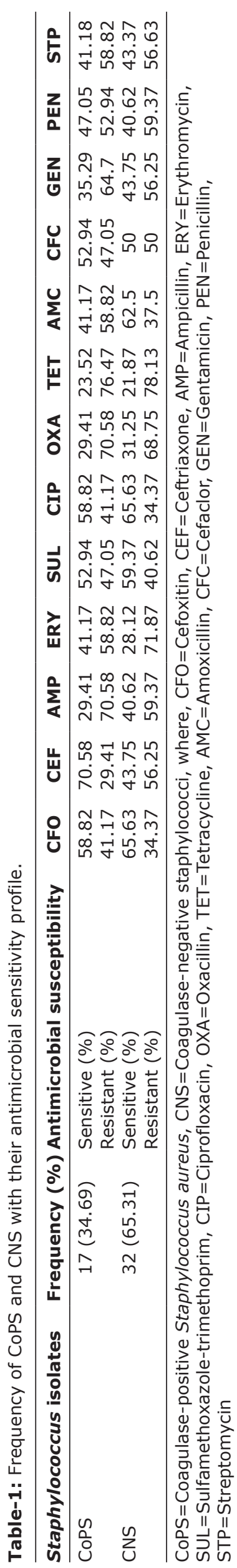

(Table-2). Of them, high body temperature $(\mathrm{p}<0.05)$, firm udder consistency $(p<0.01)$, bloodstained milk color $(p<0.00)$, and presence of pus in milk $(p<0.00)$ were statistically significant clinical conditions associated with the presence of CoPS. In the subsequent multivariable analysis, only one clinical sign (bloodstained milk color) was significantly associated $(p<0.00)$ with the carriage of CoPS.

\section{Discussion}

$S$. aureus is the most significant and commonly isolated mastitis-causing organism globally, including Bangladesh. In this study, bacteriological examination revealed that overall prevalence of staphylococci in caprine mastitis cases was $73.13 \%$ and it showed close agreement with the previous findings of $73.73 \%$ by Amin et al. [23] and $51 \%$ by Vyletelova et al. [24]. On the contrary, comparatively lower prevalence is also reported by Danmallam and Pimenov (20\%), Sarker and Samad (38.98\%), and Pirzada et al. (36.84\%) [25-27]. As Staphylococcus spp. is predominant commensal pathogen in goat bodies, for this reasons, it might be frequently associated with clinical and subclinical mastitis of goat. At the same time, healthy mammary gland environment may also favor the growth of this organism and presence of virulence factors in staphylococci subsequently aggravates the condition. The prevalence of CoPS was found $34.69 \%$, which is closely similar to the previous studies of Vyletelova et al. [24] and Haftay et al. [28] where they reported found $32.2 \%$ and $23.4 \%$ prevalence of CoPS in clinical caprine mastitis cases, respectively. In bacteriological studies, $65.30 \%$ isolates were found CNS, which is in accordance with the previous reports [27,29]. According to Bochev and Russenova [30], about $80.2 \%$ CNS are associated with subclinical mastitis in goat. The variation of prevalence might be due to geographical location, previous carriage of subclinical mastitis, variation in hygienic practices, stage of lactation, number of parity, etc. However, the methods followed by the different researchers could also be a possible reason for the variation in the prevalence of the pathogens.

A significant increase of SCC with the presence of staphylococci is one of the important features of both clinical and subclinical mastitis along with the presence of different mastitis associated clinical signs [31]. About $71.64 \%$ mastitis cases were ranked as distinct positive (2+) and SCC of the clinical samples was $>500,000-1,000,000$ cells $/ \mathrm{ml}$ using CMT, which was supported by previous findings [32,33]. In general, $S$. aureus is mainly responsible for clinical, subclinical, and chronic mastitis, often characterized by a marked increase in SCC [1].

Among the 13 antimicrobials tested against both CoPS and CNS, tetracycline was the least effective therapeutic option. However, comparatively much lower resistance profile of goat CoPS and CNS isolates to tetracycline is described by Bochev and Russenova 


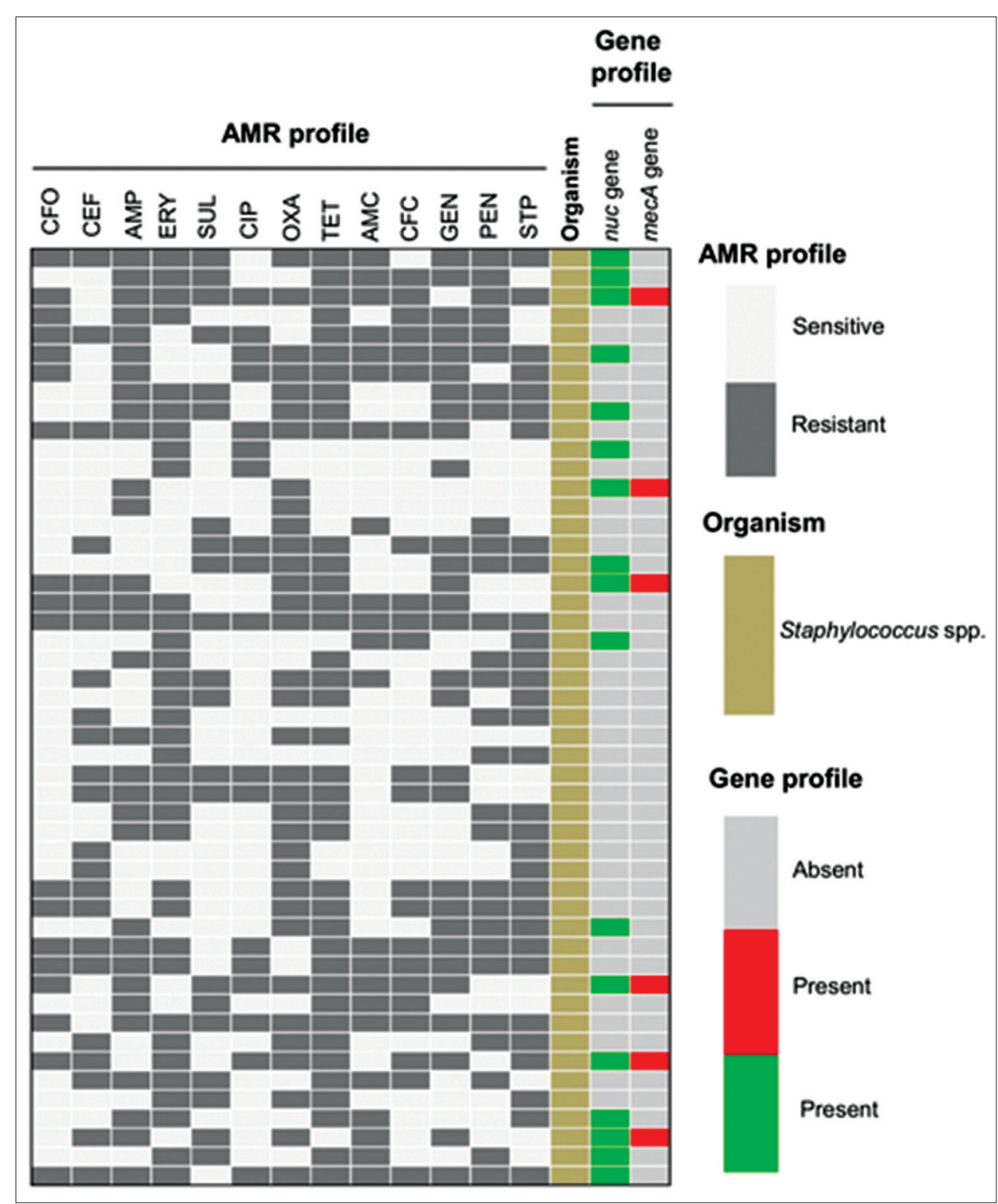

Figure-2: Heat map showing antimicrobial resistance phenotype, coagulase-positive gene (nuc), and resistance gene $(m e c A)$ profile of Staphylococcus isolates $(n=49)$ from different clinically mastitis affected goats. All intermediate resistant isolates are considered as susceptible.

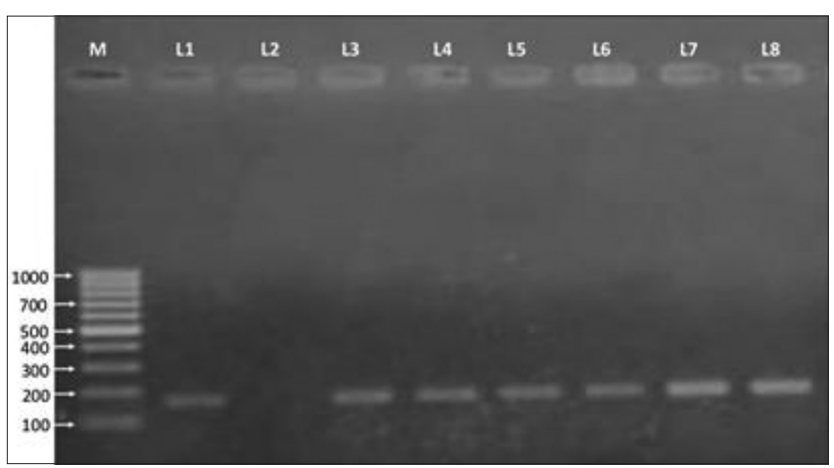

Figure-3: Gel electrophoresis image of polymerase chain reaction products of methicillin-resistant Staphylococcus aureus (MRSA) isolates showing specific amplified bands 162 bp on $1 \%$ agarose gel. $M=100$ bp DNA marker. L3-L8=MRSA-positive isolates, L2=Negative control, L1=Positive control (ATCC 33591).

and Virdis et al. [30,34]. They observed resistance rates of $16 \%$ and $24 \%$, respectively. The penicillin and ampicillin also showed marked resistance against $S$. aureus that was agreed to results reported by Bochev and Russenova [30] and Virdis et al. [34] who found $75 \%$ and $36 \%$ resistance, respectively. The resistance to penicillin and ampicillin found in this study might be of great concern since these drugs represent the main antibiotic group which is recommended for staphylococcal mastitis treatment. However, representative $\operatorname{drug}(\mathrm{s})$ from other groups of antimicrobials such as erythromycin (macrolides), gentamycin and streptomycin (aminoglycosides), and sulfamethoxazole-trimethoprim (sulfonamides) showed remarkable resistance against staphylococcal isolates tested in this study.

Our study first reports the prevalence and circulation of MRSA in mastitic goats in Bangladesh. Since the study was conducted in veterinary hospital where only clinical goats get admitted, we found a very low MRSA prevalence, with only $6(8.96 \%)$ out 
Table-2: Association of nuc gene carriage $S$. aureus positive clinical mastitis with different clinical parameters of mastitis affected goats.

\begin{tabular}{|c|c|c|c|c|c|}
\hline Variables & Covariables & $\begin{array}{l}\text { No. of mastitic } \\
\text { goats }\end{array}$ & $\begin{array}{l}\text { No. of } S \text {. aureus positive } \\
\text { for nuc gene }(\%)\end{array}$ & $95 \% \mathrm{CI}$ & p-value \\
\hline \multirow[t]{3}{*}{ Body temperature } & Higher $\left(\geq 104^{\circ} \mathrm{F}\right)$ & 34 & $11(32.35)$ & $19.04-49.25$ & $0.05^{*}$ \\
\hline & Optimum $\left(101^{\circ}-103^{\circ} \mathrm{F}\right)$ & 27 & $3(11.12)$ & $3.03-28.88$ & \\
\hline & Subnormal $\left(\leq 100^{\circ} \mathrm{F}\right)$ & 6 & $3(50)$ & $18.76-81.24$ & \\
\hline \multirow[t]{3}{*}{ Udder consistency } & Firm & 31 & $6(19.35)$ & $8.82-36.65$ & $0.01^{*}$ \\
\hline & Normal & 24 & $4(16.67)$ & $6.07-36.47$ & \\
\hline & Soft & 12 & $7(58.34)$ & $31.89-80.74$ & \\
\hline \multirow[t]{3}{*}{ Udder color } & Blackish & 6 & $3(50)$ & $18.76-81.24$ & 0.17 \\
\hline & Normal & 35 & $10(28.57)$ & $16.19-45.20$ & \\
\hline & Reddish & 26 & $4(15.38)$ & $5.53-34.15$ & \\
\hline \multirow[t]{2}{*}{ Udder inflammation } & Yes & 44 & $11(25)$ & $14.43-39.59$ & 0.92 \\
\hline & No & 23 & $6(26.08)$ & $12.26-46.76$ & \\
\hline \multirow[t]{2}{*}{ Pain in udder } & Yes & 49 & $13(26.53)$ & $16.10-40.37$ & 0.71 \\
\hline & No & 18 & $4(22.23)$ & $8.47-45.75$ & \\
\hline \multirow[t]{3}{*}{ Milk color } & Bloodstained & 23 & $14(60.86)$ & $40.73-77.90$ & $0.00^{*}$ \\
\hline & Normal & 10 & $1(10.0)$ & $0.01-42.60$ & \\
\hline & Watery & 34 & $2(5.88)$ & $0.65-20.07$ & \\
\hline \multirow[t]{3}{*}{ Udder temperature } & Cold & 4 & $2(50)$ & $15.0-85.0$ & 0.49 \\
\hline & Hot & 45 & $11(24.45)$ & $14.08-38.82$ & \\
\hline & Normal & 18 & $4(22.23)$ & $8.47-45.75$ & \\
\hline \multirow[t]{2}{*}{ Flack in milk } & Yes & 49 & $14(28.57)$ & $17.76-42.50$ & 0.32 \\
\hline & No & 18 & $3(16.67)$ & $5.01-40.05$ & \\
\hline \multirow[t]{2}{*}{ Pus in milk } & Yes & 35 & $14(40.0)$ & $25.52-56.46$ & $0.00^{*}$ \\
\hline & No & 32 & $3(9.37)$ & $2.46-25.0$ & \\
\hline \multirow[t]{3}{*}{ Feed intake } & Optimum & 20 & $3(15.0)$ & $4.39-36.88$ & 0.21 \\
\hline & Decrease & 41 & $11(26.82)$ & $15.56-42.07$ & \\
\hline & Anorexia & 6 & $3(50.0)$ & $18.76-81.24$ & \\
\hline \multirow[t]{3}{*}{ Heart rate } & Normal & 28 & $5(17.85)$ & $7.41-36.06$ & 0.11 \\
\hline & Increase & 34 & $12(35.29)$ & $21.42-52.15$ & \\
\hline & Decrease & 5 & $0(0.00)$ & $0-48.91$ & \\
\hline \multirow[t]{3}{*}{ Respiration rate } & Normal & 31 & $6(19.35)$ & $8.82-36.65$ & 0.13 \\
\hline & Increase & 31 & $11(35.48)$ & 21.53-53.12 & \\
\hline & Decrease & 5 & $0(0.00)$ & $0-48.91$ & \\
\hline \multirow[t]{2}{*}{ Milk production } & Optimum & 12 & $1(8.33)$ & $0.01-37.53$ & 0.13 \\
\hline & Decrease & 55 & $16(29.09)$ & $18.70-42.21$ & \\
\hline \multirow[t]{2}{*}{ Appearance } & Healthy & 39 & $9(23.07)$ & $12.44-38.54$ & 0.61 \\
\hline & Dull and depressed & 28 & $8(28.57)$ & $15.07-47.24$ & \\
\hline \multirow[t]{2}{*}{ Gangrene in udder } & Absence & 60 & $14(23.34)$ & $14.32-35.55$ & 0.26 \\
\hline & Presence & 7 & $3(42.85)$ & $15.75-75.02$ & \\
\hline
\end{tabular}

CI=Confidence interval, significance $*(\leq 0.05)$

of 67 cases tested. However, 20\% MRSA prevalence in mastitic goat was previously described by Bochev and Russenova [30]. In Italy, Carfora et al. [35] and Cortimiglia et al. [36] reported a very low MRSA prevalence in sheep $(0.34 \%)$ and goat $(1.3 \%)$ farms, respectively. Whereas, MRSA prevalence rate varying from 0 to $29 \%$ was reported earlier by Vanderhaeghen et al., Schlotter et al., and Luini et al. [37-39] in mastitis affected dairy cattle herds.

In this study, carriage of staphylococci and clinical examination of the mastitic udder was carried out. Through clinical examination of goat udder, we identified different clinical parameters which commonly denote mastitis. In goat, CoPS is mainly associated with clinically evident mastitis and it is related to different clinical findings such as high body temperature, firm udder consistency, bloodstained milk, and presence of pus in mastitic milk $[1,40,41]$. Hence, clinical examination of mastitic patient is the first tool of diagnosis which is easy, economical, and rapid as well. In our opinion, clinical examination of the goat udder is an utmost important diagnostic tool along with the classical microbiological approach of culturing suspected milk sample to diagnose clinical mastitis.

However, potential transmission of MRSA from animal to human has already been published, indicating a serious risk might be involved with this zoonotic pathogen [8]. Transmission of MRSA from goat to farmers, veterinary professionals, as well as milk processing personnel will result in serious public health consequences in the end.

\section{Conclusion}

In the present study, the prevalence of CoPS and CNS found in mastitic goat was $34.69 \%$ and $65.30 \%$, respectively. Between CoPS and CNS, CNS was the most frequent bacterial group associated with clinical mastitis. An exigent issue is that both the CoPS and CNS were MDR. CoPS were carrying $m e c A$ gene $(8.96 \%)$ which has potential zoonotic significance. The significant clinical conditions associated with the presence of CoPS were increased body temperature, 
firm udder consistency, bloodstained milk, and pus in milk that help in definite diagnosis and treatment of mastitic goat. Hence, it can be said that the identification of the specific organism(s) responsible for the caprine clinical mastitis and exploration of antimicrobials resistance profile of these organisms are of utmost importance for the development of an effective control program and treatment strategies.

\section{Authors' Contributions}

EAR Planned, designed, and organized the present study, conducted the laboratory task, including isolation and identification of bacteria, molecular method (PCR), statistical analyses, and primary drafting of the manuscript. TD, $\mathrm{AD}$, and NA were responsible for the literature review, results interpretation, and guided for the manuscript preparation. MR and MBB were responsible for the sample and data collection as well as clinical examination of the animals. HB Supervised the full study and revised the final manuscript. All authors have read and approved the final manuscript.

\section{Acknowledgments}

The authors are very grateful to Teaching Veterinary Hospital of Chattogram Veterinary and Animal Sciences University (TVH-CVASU) for supporting sample collection during the study period. This research was financially supported by internal funding of the Department of Microbiology and Veterinary Public Health, Chattogram Veterinary and Animal Sciences University, Chattogram, Bangladesh.

\section{Competing Interests}

The authors declare that they have no competing interests.

\section{Publisher's Note}

Veterinary World remains neutral with regard to jurisdictional claims in published map and institutional affiliation.

\section{References}

1. Marogna, G., Pilo, C., Vidili, A., Tola, S., Schianchi, G. and Leori, S.G. (2012) Comparison of clinical findings, microbiological results, and farming parameters in goat herds affected by recurrent infectious mastitis. Small Rum. Res., 102(1): 74-83

2. Cortimiglia, C., Bianchini, V., Franco, A., Caprioli, A., Battisti, A., Colombo, L., Stradiotto, K., Vezzoli, F. and Luini, M. (2015) Short communication: Prevalence of Staphylococcus aureus and methicillin-resistant S. aureus (MRSA) in bulk tank milk of dairy goat farms from Northern Italy. J. Dairy Sci., 98(4): 2307-2311.

3. Ayukekbong, J.A., Ntemgwa, M. and Atabe, A.N. (2017) The threat of antimicrobial resistance in developing countries: Causes and control strategies. Antimicrob. Resist. Infect. Control., 6(1): 47.

4. El-Deeb, W., Fayez, M., Elmoslemany, A., Kandeel, M. and Zidan, K. (2018) Methicillin-resistant Staphylococcus aureus among goat farms in Eastern province, Saudi Arabia: Prevalence and risk factors. Prev. Vet. Med., 156: 84-90.

5. Hussain, M., Yaqoob, M., Riaz, A., Umar, S., Kashif, J., Memon, J. and Shaheen, S. (2017) Prevalence, bacteriology and antibiotic sensitivity profile of sub-clinical mastitis in goats in district Jhelum. Pak. J. Sci., 69(3): 240-245.

6. Caruso, M., Latorre, L., Santagada, G., Fraccalvieri, R., Miccolupo, A., Sottili, R., Palazzo, L. and Parisi, A. (2016) Methicillin-resistant Staphylococcus aureus (MRSA) in sheep and goat bulk tank milk from Southern Italy. Small Rum. Res., 135: 26-31.

7. Devriese, L.A., Van Damme, L.R. and Fameree, L. (1972) Methicillin (cloxacillin)-resistant Staphylococcus aureus strains isolated from bovine mastitis cases. Zentralbl Veterinarmed B, 19(7): 598-605.

8. Guardabassi, L., Larsen, J., Weese, J.S., Butaye, P., Battisti, A., Kluytmans, J. and Skov, R.L. (2013) Public health impact and antimicrobial selection of meticillin-resistant staphylococci in animals. J. Glob. Antimicrob. Resist., 1(2): 55-62.

9. Obaidat, M.M., Salman, A.E.B. and Roess, A.A. (2018) High prevalence and antimicrobial resistance of mecA Staphylococcus aureus in dairy cattle, sheep, and goat bulk tank milk in Jordan. Trop. Anim. Health Prod., 50(2): 405-412.

10. Grundmann, H., Aires-de-Sousa, M., Boyce, J. and Tiemersma, E. (2006) Emergence and resurgence of meticillin-resistant Staphylococcus aureus as a public-health threat. Lancet, 368(9538): 874-885.

11. Weese, J.S., Dick, H., Willey, B.M., McGeer, A., Kreiswirth, B.N., Innis, B. and Low, D.E. (2006) Suspected transmission of methicillin-resistant Staphylococcus aureus between domestic pets and humans in veterinary clinics and in the household. Vet. Microbiol., 115(1-3): 148-155.

12. Oniciuc, E.A., Nicolau, A.I., Hernandez, M. and RodriguezLazaro, D. (2017) Presence of methicillin-resistant Staphylococcus aureus in the food chain. Trends Food Sci. Technol., 61: 49-59.

13. Gopal, S. and Divya, K.C. (2017) Can methicillin-resistant Staphylococcus aureus prevalence from dairy cows in India act as potential risk for community-associated infections? A review. Vet. World, 10(3): 311.

14. Basanisi, M.G., La Bella, G., Nobili, G., Franconieri, I. and La Salandra, G. (2017) Genotyping of methicillin-resistant Staphylococcus aureus (MRSA) isolated from milk and dairy products in South Italy. Food Microbial., 62: 141-146.

15. Schroeder, J.W. (2012) Bovine mastitis and milking management. Drug. Ther., 8(4), 1-11.

16. Carfora, V., Caprioli, A., Marri, N., Sagrafoli, D., Boselli, C., Giacinti, G. and Amatiste, S. (2015) Enterotoxin genes, enterotoxin production, and methicillin resistance in Staphylococcus aureus isolated from milk and dairy products in Central Italy. Int. Dairy J., 42: 12-15.

17. Millar, B.C., Jiru, X.U., Moore, J.E. and Earle, J.A. (2000) A simple and sensitive method to extract bacterial, yeast and fungal DNA from blood culture material. J. Microbiol. Methods, 42(2): 139-147.

18. Sasaki, T., Tsubakishita, S., Tanaka, Y., Sakusabe, A., Ohtsuka, M., Hirotaki, S. and Hiramatsu, K. (2010) Multiplex-PCR method for species identification of coagulase-positive staphylococci. J. Clin. Microbiol., 48(3): 765-769.

19. Clinical and Laboratory Standards Institute. (2008) Performance Standards for Antimicrobial Disk and Dilution Susceptibility Tests for Bacteria Isolated from Animals: Approved Standard. $3^{\text {rd }}$ ed. Clinical and Laboratory Standards Institute, United States.

20. Broekema, N.M., Van, T.T., Monson, T.A., Marshall, S.A. and Warshauer, D.M. (2009) Comparison of cefoxitin and oxacillin disk diffusion methods for detection of mecA-mediated resistance in Staphylococcus aureus in a large-scale study. J. Clin. Microbiol., 47(1): 217-219.

21. Larsen, A.R., Stegger, M. and Sørum, M. (2008) Spa typing directly from a mecA, spa and pvl multiplex PCR assay-a cost-effective improvement for methicillin-resistant Staphylococcus aureus surveillance. Clin. Microbiol. 
Infect., 14(6): 611-614.

22. R Core Team. (2016) R: A Language and Environment for Statistical Computing. R Foundation 495 for Statistical Computing, Vienna, Austria. Available from: https:// www.r-project.org.

23. Amin, M.A., Samad, M.A. and Rahman, A.A. (2011) Bacterial pathogens and risk factors associated with mastitis in Black Bengal goats in Bangladesh. Bangla. J. Vet. Med., 9(2): $155-159$

24. Vyletelova, M., VlkoVá, H. and Manga, I. (2011) Occurrence and characteristics of methicillin-resistant Staphylococcus aureus and methicillin-resistant coagulase-negative staphylococci in raw milk manufacturing. Czech J. Food Sci., 29: 11-16.

25. Danmallam, F.A. and Pimenov, N.V. (2019) Study on prevalence, clinical presentation, and associated bacterial pathogens of goat mastitis in Bauchi, Plateau, and Edo states, Nigeria. Vet. World, 12(5): 638-645.

26. Sarker, H. and Samad, M.A. (2011) Udder-halve-wise comparative prevalence of clinical and sub-clinical mastitis in lactating goats with their bacterial pathogens and antibiotic sensitivity patterns in Bangladesh. Bangla. J. Vet. Med., 9(2): 137-143.

27. Pirzada, M., Malhi, K.K., Kamboh, A.A., Rind, R., Abro, S.H., Lakho, S.A., Bhutto, K.R. and Huda, N. (2016) Prevalence of subclinical mastitis in dairy goats caused by bacterial species. J. Anim. Health Prod., 4(2): 55-59.

28. Haftay, A., Habtamu, T.M. and Abebe, M.S. (2016) Bacterial identification and antimicrobial susceptibility of subclinical mastitis causing Bacteria from goats in Aba'lla district, Afar, North-Eastern Ethiopia. Rev. Med. Vet., 167(7-8): 170-5.

29. Contreras, A., Luengo, C., Sanchez, A. and Corrales, J.C. (2003) The role of intramammary pathogens in dairy goats. Livst. Prod. Sci., 79(2-3): 273-283.

30. Bochev, I. and Russenova, N. (2005) Resistance of Staphylococcus spp. Strains isolated from goats with subclinical mastitis. Bulgar. J. Vet. Med., 8(2): 109-118.

31. Contreras, A., Sierra, D., Sánchez, A., Corrales, J.C., Marco, J.C., Paape, M.J. and Gonzalo, C. (2007) Mastitis in small ruminants. Small Rum. Res., 68(1-2): 145-153.

32. Fragkou, I.A., Boscos, C.M. and Fthenakis, G.C. (2014) Diagnosis of clinical or subclinical mastitis in ewes. Small Rum. Res., 118(1-3): 86-92.
33. Gelasakis, A.I., Angelidis, A.S., Giannakou, R., Filioussis, G., Kalamaki, M.S. and Arsenos, G. (2016) Bacterial subclinical mastitis and its effect on milk yield in low-input dairy goat herds. J. Dairy Sci., 99(5): 3698-3708.

34. Virdis, S., Scarano, C., Cossu, F., Spanu, V., Spanu, C. and De Santis, E.P.L. (2010) Antibiotic resistance in Staphylococcus aureus and coagulase-negative staphylococci isolated from goats with subclinical mastitis. Vet. Med. Int., 2010: 517060.

35. Carfora, V., Giacinti, G., Sagrafoli, D., Marri, N., Giangolini, G., Alba, P. and Amatiste, S. (2016) Methicillinresistant and methicillin-susceptible Staphylococcus aureus in dairy sheep and in-contact humans: An intra-farm study. J. Dairy Sci., 99(6): 4251-4258.

36. Cortimiglia, C.E.A., Bianchini, V., Franco, A., Caprioli, A., Battisti, A., Colombo, L. and Luini, M. (2015) Prevalence of Staphylococcus aureus and methicillin-resistant S. aureus in bulk tank milk from dairy goat farms in Northern Italy. $J$. Dairy Sci., 98(4): 2307-2311.

37. Vanderhaeghen, W., Hermans, K., Haesebrouck, F. and Butaye, P. (2010) Methicillin-resistant Staphylococcus aureus (MRSA) in food production animals. Epidemiol. Infect., 138(5): 606-625.

38. Schlotter, K., Huber-Schlenstedt, R., Gangl, A., Hotzel, H., Monecke, S., Müller, E. and Ehricht, R. (2014) Multiple cases of methicillin-resistant CC130 Staphylococcus aureus harboring mecC in milk and swab samples from a Bavarian dairy herd. J. Dairy Sci., 97(5): 2782-2788.

39. Luini, M., Cremonesi, P., Magro, G., Bianchini, V., Minozzi, G., Castiglioni, B. and Piccinini, R. (2015) Methicillin-resistant Staphylococcus aureus (MRSA) is associated with low within-herd prevalence of intra-mammary infections in dairy cows: Genotyping of isolates. Vet. Microbiol., 178(3-4): 270-274.

40. Moroni, P., Pisoni, G., Antonini, M., Ruffo, G., Carli, S., Varisco, G. and Boettcher, P. (2005) Subclinical mastitis and antimicrobial susceptibility of Staphylococcus caprae and Staphylococcus epidermidis isolated from two Italian goat herds. J. Dairy Sci., 88(5): 1694-1704.

41. Da Silva, E.R., Siqueira, A.P., Martins, J.C.D., Ferreira, W.P.B. and da Silva, N. (2004) Identification and in vitro antimicrobial susceptibility of Staphylococcus species isolated from goat mastitis in the Northeast of Brazil. Small Rum. Res., 55(1-3): 45-49.

$* * * * * * * *$ 